\title{
Benchmarking for Energy Efficiency
}

\author{
Mohd Najib Mohd Salleh¹, Mohd Zin Kandar², \\ Siti Rasidah Md Sakip ${ }^{3}$ \\ 1 School of Housing, Building \& Planning, \\ Universiti Sains Malaysia, 11800 USM, Penang, Malaysia \\ 2 Faculty of Build Environment, \\ Universiti Teknologi Malaysia, 81310 UTM, Johor, Malaysia, \\ ${ }^{3}$ Faculty of Architecture, Planning \& Surveying, \\ Universiti Teknologi MARA Perak, 32610 Seri Iskandar, Perak, Malaysia \\ najib@usm.my, drzin2000@yahoo.com, sitir704@perak.uitm.edu.my
}

\begin{abstract}
Increased energy demand end to the world grew by $39 \%$ between 1990 to 2008 and further increased by $40 \%$ between 2007 to 2030 . Energy consumption in buildings has been identified to contribute up to $40 \%$ of the total world. Through the selection of methods and the right strategy will reduce the problem of increase energy in buildings. Based on the theory of energy efficiency developed it can achieve through three main factors; a) building design; b) design of services; c) user behavior. This paper aims to discuss methods to benchmark user perception on energy efficiency in school buildings.
\end{abstract}

Keywords: Benchmarking; energy efficiency; school building; user perception

eISSN 2398-4279 @ 2018. The Authors. Published for AMER ABRA cE-Bs by e-International Publishing House, Ltd., UK. This is an open access article under the CC BY-NC-ND license (http://creativecommons.org/licenses/bync-nd/4.0/). Peer-review under responsibility of AMER (Association of Malaysian Environment-Behaviour Researchers), ABRA (Association of Behavioural Researchers on Asians) and CE-Bs (Centre for EnvironmentBehaviour Studies), Faculty of Architecture, Planning \& Surveying, Universiti Teknologi MARA, Malaysia.

DOI: https://doi.org/10.21834/ajqol.v3i10.94 


\subsection{Introduction}

Rising energy demand in buildings can reduce by improving the efficiency of energy use. However, based upon previous studies showing the business is not an easy task. Through the selection of method and the right strategy will reduce the problem of increasing energy in buildings. There are various methods used and proposed in benchmarking energy efficiency in buildings (Chung, 2011). However, very few existing methods proposed for building schools, especially in equatorial climates. Climatic conditions are believed to be difficult to give comfort to users outside or indoors with an average temperature of $27^{\circ} \mathrm{C}$ to $32^{\circ} \mathrm{C}$ and the average intensity of $500 \mathrm{~W} / \mathrm{m}^{2}$ and heat that reaches $1000 \mathrm{~W} / \mathrm{m}^{2}$ (Rahman, Samad, Bahaudin, \& Ismail, 2009). The requirements of energy-efficiency design in schools should concern duly and also not only just concerned with the reduction of energy consumption but the needs to optimize students' comfort was also a priority. The importance of energy efficiency in schools directly affects its comfortable issue and most of the time spent by students and teachers are in the school building. Comfort ness and student performance should be a priority in school next to the use of energy efficiency (Catalina \& lordache, 2012). The importance of education is gaining a place in the planning within a country, plus with the needs of information technology infrastructure gradually boost the demand for energy in school buildings. In the developed country, this importance has begun to receive more attention (Kim, Lee, \& Hong, 2012). Reduction of energy consumption in school buildings that have higher numbers is reliable indirectly can reduce operating and development expenditure. Indirectly it can influence the reduction of energy demand. These requirements influenced by referring budget statement that issued by the US Department of Energy, where as many as $25 \%$ of energy expenditure in schools can reduce through the building design and the use of energy-efficient technologies (US DOE-Energy Smart Schools, 2015)(U.S. Environmental Protection Agency, 2011). Based on the results of previous studies, the average of school energy consumption use in Malaysia is $19 \mathrm{kWj} / \mathrm{m}^{2} /$ per annum (Ibrahim, M.Z. Kandar, \& Y. Norashid, 2005). While the second result shows, the findings in the average of building energy index is $10 \mathrm{kWj} / \mathrm{m}^{2} /$ year (Salleh, 2008). The different result that based on the method used for benchmarking the energy efficiency in the buildings shows that the variety of method can use in benchmarking energy efficiency in buildings. The objective of this paper is to the measurement of the user perception of energy efficiency in school buildings towards to benchmarking energy efficiency.

\subsection{Literature Review}

Highlight Earth Summit, which results to Agenda 21, was formed from the United Nation Conference on Environment, and Development Organization (UNCED) held in Rio de Janeiro on 3 to 14 June 1992. Among the agenda was discussed during the conference was the issues of greenhouse gasses and the thinning of an ozone layer (Kubiszewski, Cleveland, Miller, \& Saundry, 2012)(Programme, 2016). The sequence of the summit conference, an assessment tool to benchmark the green building was the first developed in instances of BREEAM (UK, 1990) and LEED (USA, 1996). The intended of this benchmark is sole to reduce negative environmental effects contributed to the building through greenhouse-gas 
emissions. The resulting of benchmark criteria are intended to help designers, customers and society to consider the effect of greenhouse gas through each design produced, and the solution is through the energy efficiency and low-carbon technologies. However, the resulting benchmark is strongly influenced by the environmental factors, location, and climate. Green Building is a general term that describes sustainability for a building or development. The term is also more often understood as Green Development or Sustainable Building (Paul \& Speer, 2008) even though the building or development only involves part to the process of the formation of a Sustainable Development (Salleh, 2012). The term used is directly proportional to the understanding and benchmark criteria, and the method used. Most benchmarks have been laid criteria Energy Efficiency as a key factor in the assessment criteria. However, the benchmark for the green building does not use the same method to measure the energy efficiency of a building. Usually, the green building uses the scope of the assessment for the overall level of the building. The criteria focused to increase the efficiency of energy resources, water, and construction materials and reduce the impact of buildings on human health and environment throughout the life cycle of the building, through the placement, design, construction, operation, maintenance, enhancement and modification, and destruction (Sanchez, 2008).

\section{Energy demand}

Green building issues closely linked to the increasing of world energy demand. This issue can proved by expectations of International Energy Agency (IEA), which indicated an increase in energy in 2030 will reach as much as 40\% higher than demand in 2007 (González, Díaz, Caamano, \& Wilby, 2011). The increasing of this energy is due to the three categories of key sectors of world energy consumption; industry, transportation and others (including the residential buildings). Other sectors that include building recorded the largest increase of $36 \%$ compared to $28 \%$ for industry and $27 \%$ for the transport of energy consumption in 2008. While, energy consumption in buildings (residential, commercial, office) has been identified to contribute between $20 \%$ and $40 \%$ of total world energy consumption (WBCSD, 2009)(R. Saidur, 2009)(The IEA Website, 2010). However, the building is also capable of reducing energy consumption by $30 \%$ and $80 \%$. The increase in final energy demand in the world recorded increased by $39 \%$ between 1990 and 2008 and is expected to continue to increase by $35 \%$ between the years 2010 to 2040 have put the world on an alarming level (EXXON Mobil, 2014).

\section{Energy efficiency benchmarking in buildings}

Benchmarking is the first step that needs to be done to determine the energy performance of buildings to improve energy efficiency in the buildings (IMT Institute for Market Transformation, 2012). There are two (2) main categories in evaluating the energy efficiency performance of buildings that are "Performance-based" approach and "Feature-specific" approach. The performance-based approach is the common research approach used today. This is due to the result is believed to be accurate and reliable as the outcome can be comparable. However, it is difficult to establish this approach as it needs appropriate measures to be implemented. This approach enables the evaluation results to be compared 
based on performance indicators such as Energy Use Index (EUI) or carbon dioxide emission. The feature-specific approach allows the marks to given when the criteria are met, and the final assessment is based on the total marks obtained (Lee, Yik, \& Burnett, 2003). Energy performance evaluation and its methodology are being developed to benchmark and classify the energy performance. Energy benchmarking is the way to communicate on building efficiency and carbon gas emission to building owners. This energy classification method enables building owners or publics to obtain information on the performance of a building. There are four (4) types of energy classification were identified, which are: (1) Energy Benchmarking, (2) Energy Rating, (3) Energy Labeling and (4) Energy Certification (Perez \& Capeluto, 2009). Besides, feature-specific approach with energy performance diagnosis approach aims to identify the cause of weaknesses and provide certain measures to improve and enhance performance. This diagnosis method uses a more comprehensive approach to identifying existing weaknesses. However, it is difficult to convey the information obtained to the public due to a more detailed information and a factor of confidentiality or security (Wang, Yan, \& Xiao, 2012). Both of these approaches have in common as mentioned by Chung, (2011) where there are two types of benchmarks are being developed with different mathematical methods. This benchmark namely Public Benchmark and Internal Benchmark. The benchmark is meant the same term as the opinion Lee et al., (2003) in evaluating the energy performance of buildings. The public benchmark uses methods that can be applied and understood by public users, and the information is being channeled to the media by the regulators. Consequently, the public users consequentially giving pressure to building owners to improve the energy consumption performance. According to Al-Mofleh, Taib, Mujeebu, \& Salah, (2009) energy efficiency in buildings can be achieved through three (3) main factors namely; a) factors in the design of buildings; b) factor design services; and c) the behavior of the user (Al-Mofleh et al., 2009). However, the behavior of consumers has greatly affected energy efficiency in buildings because users have a direct relationship with the behavior of consumption in the area where the activities carried out (Hoes, Hensen, Loomans, De Vries, \& Bourgeois, 2009). Influencing consumer behavior patterns of energy consumption in buildings. This leads to judgment without involving the user can lead to the discovery of the soil. The differences in findings for energy efficiency based on expectations compared with actual scenarios will result. This is evidenced by Masoso O. (2010) in his research generated without considering factors into the analysis of user research, proving that "the period of energy waste in buildings usually occurred when it is not occupied" (Masoso \& L. Grobler, 2010). This fact shows that the behavior of consumers who do not turn toward the source of electricity when leaving a room or building leads to energy waste. Consumer behavior in buildings has attracted the attention of researchers since the 1970s in the midst of an energy crisis (Keazer, 2007). Consumer and behavior in energy research institution building very isolated as described by Ron Widman (Wang et al., 2012). The importance of research on the behavior of energy consumption in school buildings has been given attention where energy savings of between $5 \%$ to $15 \%$ can be achieved only by the change in consumer behavior at school (U.S. Environmental Protection Agency, 2011). This shows that the behaviors of consumers on energy efficiency are the real issues that affect building energy. This pilot study has been conducting the survey on consumer perceptions 
of the respondents with the aim of investigating the feedback and its impact when considered in identifying methods for energy-efficiency benchmarks in the design of school buildings. The use of the questionnaire is the most economical and effective way to collect the necessary data (Khan \& Kotharkar, 2013). Therefore, user perception of energy efficiency in school building's design (UPEESD) components is based on factors specified in Anwar AlMofleh et al., (2009), namely perception of Ventilation (POV) and Perception of Design (POD) to be represented a) factors in the design of buildings; Perception of Ventilation (POV) and Perception of Noise (PON) to be represented b) factor design services; Perception and Awareness of Energy Efficiency (PEE) to be represented $c$ ) the behavior of the user. This method will be used in the investigation of benchmark energy efficiency of the design of school buildings

\subsection{Methodology}

The main objective of this research paper is to identify the measurement of the user perception of energy efficiency in school buildings design (UPEESD) components towards methods to benchmarking energy efficiency in school buildings. Towards achieving this objective, 155 respondents were randomly selected from Sekolah Menengah Berasrama Penuh Integrasi Berprestasi Tinggi, (SBPIBT), Gopeng, Perak, Malaysia. The respondents involved in this pilot survey were standard five students. This vital as the study involves the attitude as well as the sense of responsibility towards the respondents' school area. A face to face interview approach was used for the purpose of this study to ensure that the respondents fully understood the questions that were forwarded to them. To avoid any confusion or misunderstanding, the researchers introduced themselves as well as explained the purpose of the study undertaken. The measurement design of the UPEESD components was based on the review of previous literature that is relevant to the UPEESD components. Pilot Study seeks to ensure that the sample size can be chosen to represent the total population in building research 1,011 and can reduce sampling error and increase the degree of accuracy. The trial questionnaire survey was conducted on one full working days, and it is representing ordinary working a day to another.

\subsection{Findings and Discussions}

This pilot study was conducted in school study areas were selected based on predetermined categories based on the literature. A questionnaire study conducted by the scope of the study that was designed using random sampling stages involving three stages, namely the classification of educational buildings, school location by zone and a list of schools. The study involved a sample of $10 \%$ of 60 Schools Boarding High Performance (SBPBT). This study involves the collection of qualitative data such as redraw the existing plan to measure the floor area of the school involved. Also, data on annual electricity bills needed to obtain the energy consumption data to investigate the energy performance of school buildings. Review the observations made by the checklist was used for observation of existing school design 
elements that affect energy efficiency.

\section{Measuring the perception of energy efficiency in school buildings design}

The user perception of energy efficiency in school buildings design (UPEESD) construct is based on four dimensions; (a) perception of ventilation (POV), (b) perception of design (POD), (c) perception of noise (PON) and (d) perception of energy efficiency awareness (PEE). All of these dimensions components were measured using a 5 point Likert Scale of 1 - strongly disagree, 2 - not agree, 3 - agree, 4 - highly agree and 5 - strongly agree. The validation and confirmation of all constructs were done using Exploratory Factor Analysis (EFA). EFA is used to gather information about the interrelationship among a set of variables (Pallant J., 2005). The result for the level of reliability was found by calculating the Cronbach's Alpha. The dimensions of the construct have a good reliability value as the Cronbach's Alpha value exceeds 0.60 (Nunnally \& Bernstein, 1994). From the aspects of validity and reliability, the items for each dimension; perception of comfort on ventilation (POV), the perception of design (POD), the perception of noise (PON) and perception of energy efficiency awareness (PEE) were measured using the Cronbach alpha (a) analysis. An item-to-scale value of 0.3 and above was used as the minimum value for a unidimensional scale (de Vaus, 1986) while the scale was considered reliable if the alpha value was 0.6 and above, based on the (de Vellis, 1991) criteria. The result is explained in Table 1 . The results of the analysis demonstrated that all seven items under the POV dimension were not valid to be used to measure the concerned dimension as the a value $=.07$. Also, an item-to-scale value for all items in POV is below 0.3. This finding indicates that each item in POV cannot be measured and no association between an item in measuring the POV. Therefore, the items in POV dimension were restructuring again to clarify the items to measure the POV in future research. The perception of design, it involved 14 items. One item was omitted as it recorded corrected item-to-total correlation value of below 0.3 while the total alpha value of the 13 items was $\square=.82$. The item is "Do you agree that we should use electric lighting in the classroom despite the daylight". After this item was eliminated, and analysis was redone, the resulting a value $=.83$. This illustrates that the remaining 13 items are valid in measuring the perception of design POD dimension. For the perception of noise (PON) dimension that had five items, the Cronbach alpha (a) analysis conducted resulted in an a value $=.65$. There was one item in this dimension that had to be omitted to obtain an a value $=.70$. The one item that was excluded is "Do you would switch off the fan if the fan-generated noise". Then, only four items were valid to measure the PON dimension. Meanwhile, the dimension of perception of energy efficiency awareness (PEE) contains seven items. Analysis findings have illustrated that 1 out of the seven items show a corrected item-to-total correlation value of below 0.3 while the total alpha value for the seven items was .68. Re-analysis after this item was eliminated returned an a value $=.74$. This clearly establishes that the remaining six items are valid to be used in measuring PEE. The item that was removed is "Do you agree that we should use electric lighting in the classroom despite the daylight?". This pilot study involved $58.5 \%$ female respondents and $41.5 \%$ male respondents (44\%). $97.3 \%$ of respondents involved are students with the $16 \mathrm{~s}$ to $25 \mathrm{~s}$ of age group (98.6\%), $2.1 \%$ teachers, and $0.7 \%$ is 
a school staff. $50.3 \%$ of respondents have been in this school for 3 to 4 years, and $47.6 \%$ have been in 1 to 2 years.

Table 1: Cronbach's alpha value for all variables

\begin{tabular}{|c|c|c|c|c|}
\hline $\begin{array}{l}\text { UPEESD } \\
\text { Dimensions }\end{array}$ & Items & Description of Items & $\begin{array}{l}\text { Corrected item- } \\
\text { total correlation }\end{array}$ & $\begin{array}{l}\text { Reliability } \\
\text { (Cronbach's Alpha) }\end{array}$ \\
\hline POV & $\begin{array}{l}\text { Item } 1 \\
\text { Item } 2 \\
\text { Item } 3 \\
\text { Item } 4 \\
\text { Item } 5 \\
\text { Item } 6 \\
\text { Item } 7\end{array}$ & $\begin{array}{l}\text { How often do you feel too hot } \\
\text { while having in the classroom } \\
\text { throughout the year? } \\
\text { How often do you feel too cold } \\
\text { while having in the classroom } \\
\text { throughout the year? } \\
\text { How often do you feel damp or } \\
\text { sticky in the classroom } \\
\text { throughout the year? } \\
\text { How often do you feel less } \\
\text { humid or less sticky in the } \\
\text { classroom throughout the } \\
\text { year? } \\
\text { How often do you feel there is } \\
\text { no natural ventilation in the } \\
\text { classroom throughout the } \\
\text { year? } \\
\text { How often do you feel that } \\
\text { there is excessive air } \\
\text { movement in the classroom } \\
\text { throughout the year? } \\
\text { How often are you going to } \\
\text { ensure open windows to allow } \\
\text { natural ventilation in } \\
\text { classrooms? }\end{array}$ & $\begin{array}{l}- \\
- \\
- \\
- \\
- \\
- \\
-\end{array}$ & 0.07 \\
\hline POD & $\begin{array}{l}\text { Item } 1 \\
\text { Item } 2 \\
\text { Item } 3 \\
\text { Item } 4 \\
\text { Item } 5 \\
\text { Item } 6 \\
\text { Item } 7 \\
\text { Item } 8 \\
\text { Item } 9 \\
\text { Item } 10 \\
\text { Item } 11 \\
\text { Item } 12 \\
\text { Item } 13 \\
\text { Item } 14\end{array}$ & $\begin{array}{l}\text { Do you feel hot in the morning } \\
\text { ( } 7 \text { am }-12 \text { noon ) while you } \\
\text { are in the class? } \\
\text { Do you feel hot in the afternoon } \\
\text { ( } 12 \text { noon }-2 \text { pm ) while you } \\
\text { are in the class? } \\
\text { Do you feel hot in the evening ( } \\
2 \text { pm }-7 \mathrm{pm} \text { ) while you are in } \\
\text { the class? } \\
\text { Do you feel glare in the } \\
\text { morning ( } 7 \text { am }-12 \text { noon ) } \\
\text { while you are in the class? } \\
\text { Do you feel glare in the } \\
\text { afternoon ( } 12 \text { noon }-2 \text { pm ) } \\
\text { while you are in the class? } \\
\text { Do you feel glare in the evening } \\
\text { ( } 2 \text { pm }-7 \text { pm ) while you are in } \\
\text { the class? } \\
\text { You see shadows/reflections } \\
\text { on the blackboard/ whiteboard. }\end{array}$ & $\begin{array}{l}.38 \\
.52 \\
.36 \\
.37 \\
.47 \\
.50 \\
.58 \\
.59 \\
.50 \\
.52 \\
.51 \\
.43 \\
.50 \\
-\end{array}$ & .83 \\
\hline
\end{tabular}




\begin{tabular}{|c|c|c|c|c|}
\hline & & $\begin{array}{l}\text { You notice harsh glare from } \\
\text { direct sunlight in the classroom } \\
\text { You notice harsh glare from } \\
\text { artificial light in the classroom } \\
\text { Lack of natural lighting in the } \\
\text { room. } \\
\text { There is a space that is too } \\
\text { dark. } \\
\text { Lack of natural lighting in space } \\
\text { Pencahaayaan least help in the } \\
\text { area. } \\
\text { Do you agree that we should } \\
\text { use electric lighting in the } \\
\text { classroom despite the } \\
\text { daylight? }\end{array}$ & & \\
\hline PON & $\begin{array}{l}\text { Item } 1 \\
\text { Item } 2 \\
\text { Item } 3 \\
\text { Item } 4 \\
\text { Item } 5\end{array}$ & $\begin{array}{l}\text { Too much noise from the } \\
\text { outside of building. } \\
\text { Too much noise from } \\
\text { neighboring rooms } \\
\text { Too much noise from } \\
\text { construction equipment. } \\
\text { You will ensure the windows } \\
\text { closed to avoid the noise in the } \\
\text { classroom. } \\
\text { Do you will switch off the fan if } \\
\text { the fan-generated noise }\end{array}$ & $\begin{array}{l}.52 \\
.49 \\
.57 \\
.36 \\
-\end{array}$ & .70 \\
\hline PEE & $\begin{array}{l}\text { Item } 1 \\
\text { Item } 2 \\
\text { Item } 3 \\
\text { Item } 4 \\
\text { Item } 5 \\
\text { Item } 6 \\
\text { Item } 7\end{array}$ & $\begin{array}{l}\text { Are you the one who ensures } \\
\text { that light switches in the } \\
\text { classrooms are switched off } \\
\text { when no one is using them? } \\
\text { Are you the one who ensures } \\
\text { that fan switches in the } \\
\text { classrooms are switched off } \\
\text { when no one is using them? } \\
\text { Are you aware that the use of } \\
\text { air-conditioning systems such } \\
\text { as in the library requires airtight } \\
\text { windows? } \\
\text { Are you aware that without } \\
\text { user awareness on electrical } \\
\text { energy consumption, there will } \\
\text { be electricity bill wastages in } \\
\text { the school? } \\
\text { Do you agree that the students } \\
\text { in this school are perceptive } \\
\text { towards energy consumption in } \\
\text { school? } \\
\text { Do you agree that the teachers } \\
\text { in this school are perceptive } \\
\text { towards energy consumption in } \\
\text { school? } \\
\text { Do you agree that we should } \\
\text { use electric lighting in the }\end{array}$ & $\begin{array}{l}.61 \\
.63 \\
.46 \\
.35 \\
.45 \\
.39 \\
-\end{array}$ & .74 \\
\hline
\end{tabular}


classroom despite the daylight?

\subsection{Conclusion}

This pilot study aims to assess the credibility to the research planned before it is implemented. This approach is to identify the authenticity and reliability of the questionnaire were designed before they are used in actual field work (de Vaus, 1986). This pilot study also serves to identify problems that might arise from the actual study. It aims to assess the suitability of the research question (Piaw, 2009). This pilot study has found several problems with the structure of sentences and the use of a Likert scale of 5 points. POV Dimensions in UPEESD component will be eliminated from the actual study. This is because the correlation between the item and the item is found to show a weak correlation. Through observation, it was found that the susceptibility of these components can be replaced by measurement using measurement equipment. In general, this pilot study has found that the use of a questionnaire to identify the behavior and reactions of the respondents to the component user perception of energy efficiency in school building's design (UPEESD) is effective and sensitive. This demonstrates the ability to recognize the relationship between the various variables in proving this method can be used for the investigation of benchmark energy efficiency at the design of school buildings for user perception of energy efficiency in school building's design (UPEESD) components.

\section{Acknowledgement}

The researcher would like to express gratitude towards the supervisor in giving guidance and pointers, as well as constructive criticism throughout the implementation of this pilot study. The Ministry of Education Malaysian (KPM) and Sekolah Menengah Berintegrasi Berprestasi Tinggi, Gopeng, Perak is also accorded with thanks to their support and cooperation in furnishing the relevant statistical data for Malaysia.

\section{References}

Al-Mofleh, A., Taib, S., Mujeebu, M. A., \& Salah, W. (2009). Analysis of sectoral energy conservation in Malaysia. Energy, 34(6), 733-739. Retrieved from http://dx.doi.org/10.1016/j.energy.2008.10.005

Catalina, T., \& lordache, V. (2012). IEQ assessment on schools in the design stage. Building and Environment, 49(1), 129-140. Retrieved from http://dx.doi.org/10.1016/j.buildenv.2011.09.014

Chung, W. (2011). Review of building energy-use performance benchmarking methodologies. Applied Energy, 88(5), 1470-1479. http://doi.org/10.1016/j.apenergy.2010.11.022

de Vaus, D. A. (1986). Surveys In Social Research. London, Academic Divison Of Unwin Hyman Ltd.

de Vellis, R. F. (1991). Scale Development: Theory and Aplication. Thousand Oaks, CA, Sage. 
EXXON Mobil. (2014). The outlook for energy: A view to 2040 Texas.

González, A. B. R., Díaz, J. J. V., Caamano, A. J., \& Wilby, M. R. (2011). Towards a universal energy efficiency index for buildings. Energy and Buildings, 43(4), 980-987.

Hoes, P., Hensen, J. L. M., Loomans, M. G. L. C., De Vries, B., \& Bourgeois, D. (2009). User behavior in whole building simulation. Energy and Buildings, 41(3), 295-302. http://doi.org/10.1016/j.enbuild.2008.09.008

Ibrahim, K., M.Z. Kandar, \& Y. Norashid. (2005). Koleksi pertandingan projek kecekapan tenaga diperbaharui (KT\&DT) sekolah-sekolah menengah Se Malaysia 2003.

IMT Institute for Market Transformation. (2012). Promoting energy efficiency in buildings. Retrieved from http://www.imt.org/

Keazer, J. A. (2007). A Study Of Arkansas K-12 School Building Energy Requirements And An Evaluation Of Improvements Toward Energy Efficiency Using Building Energy Simulations. University Of Arkansas.

Khan, S., \& Kotharkar, R. (2013). Methodological Approaches to Assessing Child Centricity in Urban Schools of India. Journal of ASIAN Behavioural Studies, 3, 79-94.

Kim, T. W., Lee, K. G., \& Hong, W. H. (2012). Energy consumption characteristics of the elementary schools in South Korea. Energy and Buildings, 54, 480-489. http://doi.org/10.1016/j.enbuild.2012.07.015

Kubiszewski, I., Cleveland, C. J., Miller, M., \& Saundry, P. (2012). United Nations Conference on Environment and Development (UNCED), Rio de Janeiro, Brazil. Retrieved April 14, 2016, from http://www.eoearth.org/view/article/156773/

Lee, W. L., Yik, F. W. H., \& Burnett, J. (2003). A method to assess the energy performance of existing commercial complexes. Indoor and Built Environment, 12, 311-327.

Masoso, O., \& L. Grobler, L. (2010). The Dark Side Of Occupants' Behavour On Building Energy Use. Energy and Buildings, 42, 173-177.

Nunnally, J. C., \& Bernstein, I. H. (1994). Psyhometric Theory. New York: Mcgraw-Hill.

Pallant J. (2005). Spss Survival Manual; A Step By Step Guide To Data Analysis Using Spss For Window. Sydney, Australia.

Paul, N. A. P., \& Speer, P. W. (2008). Linking Organizational Characteristics to Psychological Empowerment: Contextual Issues in Empowerment Theory. Administration in Social Work, 3107(October 2014), 37-41.

Perez, Y. V., \& Capeluto, I. G. (2009). Climatic considerations in school building design in the hot-humid climate for reducing energy consumption. Applied Energy, 86(3), 340-348. http://doi.org/10.1016/j.apenergy.2008.05.007

Piaw, C. Y. (2009). Kaedah dan Statistik Penyelidikan; Statistik Penyelidikan Lanjutan Ujian Regresi, Analisis Faktor dan Analisis SEM. McGraw Hill Education.

Programme, U. N. E. (2016). United Nations Environment Programme environment for development. Retrieved January 14, 2016, from http://www.unep.org/about/

R. Saidur. (2009). Energy consumption, energy savings, and emission analysis in Malaysian office buildings. Energy Policy, 37(10), 4104-4113. http://doi.org/10.1016/j.enpol.2009.04.052 
Rahman, A. M. A., Samad, M. H. A., Bahaudin, A., \& Ismail, M. R. (2009). Towards A Low-Energy Building Design for Tropical Malaysia. Universiti Sains Malaysia.

Salleh, M. N. M. (2008). Reka Bentuk Sekolah Kebangsaan Daripada Aspek Kecekapan Tenaga: Kajian Kes Daerah Perak Tengah. Universiti Sains Malaysia.

Salleh, M. N. M. (2012). Gerakan baru Dalam Senibina Lestari: Buuh Sebagai Sumber Dan Bahan Binaan Untuk Bangunan Hijau. Habitat Magazine, 29.

Sanchez, Y. (2008). Cmgt-564 Catholic University of America. Retrieved from http://www.nahbgreen.org/About/greenhomebuilding.aspx

The IEA Website. (2010). The IEA Website. Retrieved from http://www.iea.org/

U.S. Environmental Protection Agency. (2011). Energy Efficiency Programs in K-12 Schools. Retrieved from http://www.epa.gov/statelocalclimate/documents/pdf/k-12_guide.pdf

US DOE-Energy Smart Schools. (2015). US Department of Energy Energy Efficiency and Renewable Energy, Building Technologies Program.

Wang, S., Yan, C., \& Xiao, F. (2012). Quantitative energy performance assessment methods for existing buildings. Energy and Buildings, 55, 873-888. http://doi.org/10.1016/j.enbuild.2012.08.037

WBCSD. (2009). Energy efficiency in buildings-transforming the market. 